20. Guidance on $\mathrm{Al}$ and data protection // Information commissioner's office official website. URL: https://ico org uk/for-organisations/guide-todata-protection/key-data-protection-themes/guidance-on-artificial-intelligenceand-data-protection/ (acceed: 07.04.2021)

21. Using Artificial Intelligence and Algorithms // FTC official website, Apr 8 2020. URL: https://www.ftc.gov/news-events/blogs/businessblog/2020/04/using-artificial-intelligence-algorithms (acceed: 07.04.2021).

22. A guide to good practice for digital and data-driven health technologies. Updated 19 January 2021 // UK's Department of Health and Social Care. URL: https://www.gov.uk/government/publications/code-ofconduct-for-data-driven-health-and-care-technology/initial-code-of-conductfor-data-driven-health-and-care-technology (acceed: 10.03.2021)

23. Open Ethics Initiative. Ethics as Open Data. URL: https://openethics.ai/ (acceed:10.03.2021).

24. Sandbox for responsible artificial intelligence // Datatilsynet website. URL: https://www.datatilsynet.no/en/regulations-and-tools/sandbox-for-artificialintelligence/ (acceed: 07.04.2021)

25. Braychevs'kyy S.M. Problema personal'nykh danykh v systemakh internetu rechey z elementamy shtuchnoho intelektu. Informatsiya i pravo.

V. Nekrutenko, PhD Student

Taras Shevchenko National University of Kyiv, Kyiv, Ukraine
[The problem of personal data in the systems of the internet of things with elements of artificial intelligence. Information and law.] No 4(31)/2019. URL: https://ippi.org.ua/sites/default/files/9_13.pdf (acceed: 05.11.2021).

26. Katkova T. H. Shtuchnyy intelekt $v$ ukrayini: pravovi aspekty. Zhurnal "Pravo i Suspil'stvo" [Artificial intelligence in Ukraine: legal aspects. Magazine "Law and Society"] No6/2020. Kharkiv - 2020. URL: http://pravoisuspilstvo.org.ua/archive/2020/6 2020/10.pdf (acceed: 05.11.2021).

27. Horodys'kyy I.M. Tendentsiyi rozvytku pravovoho rehulyuvannya shtuchnoho inteleku $v$ Yevropeys'komu Soyuzi. IT pravo: problemy i perspektyvy rozvytku $\vee$ Ukrayini (druha mizhnarodna shchorichna konferentsiya) [Trends in the development of legal regulation of artificial intelligence in the European Union. IT law: problems and prospects of development in Ukraine (second international annual conference)]. Lviv 2017. URL: http://aphd.ua/publication-388/ (acceed: 05.11.2021).

Received: $05 / 05 / 2021$ $1^{\text {st }}$ Revision: $01 / 07 / 2021$ Accepted: $20 / 09 / 2021$

\title{
ON THE SYSTEMATISATION OF RISKS CAUSED BY THE PROCESSING OF PERSONAL DATA USING ARTIFICIAL INTELLIGENCE TECHNOLOGIES
}

The purpose of the study in this article is to systematise the risks that may be caused by the processing of personal data using artificial intelligence technologies, according to the criteria of stages of personal data processing and legislation that may be violated due to those risks. Based on the systematisation of risks, the aim was also to analyse the means of preventing and minimising the risks caused by the use of artificial intelligence technologies.

To achieve the purpose of this work, the following methods were used: structural, functional, systemic, comparative, as well as the method of analysis. Among the special scientific methods are methods of systematic and dynamic interpretation of legislation in the field of personal data protection.

The study analysed in accordance with the legislation of Ukraine and systematised legal risks caused by the processing of personal data using artificial intelligence technologies; identified factors and interests with which it is necessary to balance the minimisation of legal risks; proposed components of a comprehensive regulatory system aimed at minimising risks and ensuring a balance between the interests of individuals and organisations that collect and process personal data. The obtained results allowed to come to the following conclusions: 1) The use of artificial intelligence algorithms in human interaction gives undeniable advantages and social benefits; 2) Unregulated use of this technology poses significant risks of violation of the human right for respect for private life and the right to protection of personal data. The main aspects of such risks are the illegal use of collected personal data for machine learning, opacity and loss of control over the logic of decision-making, as well as the risks of breach of personal data security; 3) In order to minimise risks and ensure a balance between private and public interest, it is necessary to find a comprehensive approach that involves all stakeholders. An integrated approach involves the application of mandatory rules of conduct and the rules of so-called soft law.

Keywords: personal data protection; personal data; Artificial Intelligence; innovative technologies; privacy; machine learning; discrimination.

Bulletin of Taras Shevchenko National University of Kyiv. Legal Studies, 2021; 4 (119): 59-63

удК 340.12

DOI: https:doi.org/10.17721/1728-2195/2021/4.119-11
ISSN 1728-2195

(C) Taras Shevchenko National University of Kyiv, Publishing center "Kyiv University", 2021

Г. 3. Остапенко, канд. юрид. наук, доц. ORCID ID: 0000-0003-0529-2551

Київський національний університет імені Тараса Шевченка, Київ, Україна

\section{ПРАВОВА ВИЗНАЧЕНІСТЬ У КОНТЕКСТІ РЕФОРМИ МІСЦЕВОГО САМОВРЯДУВАННЯ}

Висвітлено питання дотримання правової визначеності у процесі реалізації повноважень органами місцевого самоврядування, що були значно розширені в ході проведення реформи місцевого самоврядування. Визначено, що у процесі здійснення органами державної влади повноважень, які в ході реформи були передані до органів місцевого самоврядування, важливим був принцип правової визначеності. Цей принцип вимагає чіткості і зрозумілості законодавчих положень, передбачуваності рішень органів влади, обмеження дискреційних повноважень, вимогу до оприлюднення правових актів і доведення їх до відома громадян наперед та інші елементи. Стверджуеться, що ці ж вимоги, які складають зміст принципу правової визначеності, мають бути застосовані і у процесі реалізації повноважень органами місцевого самоврядування.

Одним з аспектів правової визначеності визнається поваеа до легітимних очікувань громадян, натомість проаналізована судова практика свідчить, що численними є випадки порушення цієї вимоги правової визначеності під час реалізації повноважень органами місцевого самоврядування. Акцентується увага на недопущенні подібної практики та на необхідності дотримання правової визначеності як обов'язкової вимоги верховенства права.

Визначено необхідність дотримання вимог правової визначеності під час оприлюднення актів органами місцевого самоврядування і доведення їхнього змісту до відома громадян.

Ключові слова: місцеве самоврядування, правова визначеність, легітимні очікування, визначеність законодавства, верховенство права, децентралізація.

\section{ВСТуП}

Реформа місцевого самоврядування є умовою демократизації, децентралізації та одним із проявів народовладдя, що визнає право вирішувати питання місцевого значення безпосередньо територіальними громадами, прав та інтересів яких такі питання стосуються. Нині реформа місцевого самоврядування пройшла відповідні етапи, адже після формування територіальних громад, проведення місцевих виборів, відбулося формування нових органів, які наділені необхідною компетенцією для вирішення питань місцевого значення. Питання, які раніше належали до сфери відання державних органів, були передані органам місцевого самоврядування, які набули не тільки прав, а й обов'язків перед членами громади за їхнє здійснення. Отже, постає питання належного здійснення таких повноважень. Ви- 
значальним у відносинах між громадянами й органами державної влади, яким до реформи належали ці повноваження, був принцип правової визначеності. Отже, логічно припустити, що актуальним у контексті реформи місцевого самоврядування $€$ збереження вимоги дотримання цього принципу, адже заміна суб'єкта не повинна спричинити дисбалансу між інтересами носія влади і суб'єктами прав під час здійснення повноважень. Децентралізація потребує більш детальної уваги до дотримання правової визначеності, передбачуваності та захисту легітимних очікувань, через здійснення публічної влади органами місцевого самоврядування, які в певних випадках наділені ширшою, порівняно 3 органами державної влади, автономією.

Метою дослідження $€$ аналіз дотримання правової визначеності в контексті реформи місцевого самоврядування.

Аналіз останніх досліджень і публікацій. Питання застосування принципу правової визначеності в організації та діяльності органів місцевого самоврядування частково досліджувався такими вченими, як: Л. М. Андрусів, М. О. Петришиною, Х. В. Приходько, В.І.Пилиповим, Т. О. Коломоєць та ін. Принцип правової визначеності ставав предметом дослідження В. О. Панкратової, Ю. І. Матвєєвої, М.І.Козюброю та іншими дослідниками.

\section{ВИКЛАД ОСНОВНОГО МАТЕРІАЛУ}

Право територіальної громади самостійно вирішувати питання місцевого значення реалізується через представницькі органи місцевого самоврядування, які внаслідок проведення перших етапів реформи децентралізації отримали значно ширші повноваження. Важливо відмітити, що ідеєю, покладеною в основу реформи було надання громадянам можливості вирішувати питання місцевого значення у найбільшій відповідності з їхніми інтересами, раціонально використовуючи кошти на потреби громади. Розширення повноважень органів місцевого самоврядування здійснювалося з усвідомленням цієї мети, здійснення їх також має відбуватись відповідно до неї. Як зазначає О. В. Чернецька "представницькі органи місцевого самоврядування $\epsilon$ необхідним елементом механізму формування та вираження волі територіальної громади, що у свою чергу і визначає їхнє пріоритетне місце в системі органів місцевого самоврядування. Разом із тим, незважаючи на абсолютно незаперечний теоретичний підхід щодо визначення пріоритетності представницького органу в системі органів місцевого самоврядування, українські реалії функціонування цих інституцій не підтверджують свого істинного значення для життєдіяльності територіальної громади на практиці" [13, с. 121]. Така проблема ставить питання про необхідність дослідження принципу правової визначеності в контексті проведення реформи місцевого самоврядування, зокрема і питання про дотримання правової визначеності у реалізації повноважень органами місцевого самоврядування.

Відсутність єдиного кодифікованого акта, велика кількість нормативних актів різної форми та їхня перманентна зміна, значне оновлення законодавства щодо місцевого самоврядування створюють підґрунтя для невизначеності, а велика варіативність у їхньому здійсненні на місцях ставить питання про узгодженість цих дій і рішень із принципом правової визначеності. Ці питання піднімають дослідники проблем місцевого самоврядування та його окремих аспектів.

$\mathrm{Ha}$ проблему дотримання правової визначеності в контексті забезпечення рівності прав на службу в органах місцевого самоврядування звертає увагу В. І. Пилипів. На його думку, принцип рівності гарантує визначеність законодавства (тобто, він тісно пов'язаний із принципом правової визначеності) та означає: дотримання вимог до визначеності законодавства, у якому має міститись принцип рівності, дотримання вимог до визначеності судових рішень, які мають прийматись із дотриманням принципу рівності; дотримання вимог до визначеності меж повноважень органів публічної влади, які при їхньому здійсненні мають дотримуватися принципу рівності" [7, с. 78].

Однією з проблем, що спонукала до проведення децентралізації стояло завдання побороти корупцію в органах державної влади, що була особливою проблемою на місцевому рівні. У цьому контексті роль принципу правової визначеності видається значною. Як зазначає Т. О. Коломоєць, "використання ресурсу "антикорупційних" обмежень для осіб, уповноважених на виконання функцій держави або місцевого самоврядування, у сучасних умовах докорінного перегляду змісту вітчизняного антикорупційного законодавства та пошуку ефективних "інструментів" запобігання корупції у всіх її проявах, слід розглядати з акцентом на підвищення "якості" їхньої правової визначеності як елемента принципу верховенства права". Автор наводить поняття "дефектності" правової визначеності і пропонує для підвищення "якості" правової визначеності шляхи, зокрема, мінімізувати використання оціночних понять, замінивши їх вичерпним переліком типових випадків; мінімізувати наявність відсильних, бланкетних норм; деталізувати процедурні засади та зміст обмежень, які використовуються 3 метою унеможливлення корупції; підвищувати правопросвітницьку діяльність [3, с. 88]. Можна стверджувати, що дотримання правової визначеності вимагається незалежно від того, чи здійснюється органами державної влади чи органами місцевого самоврядування така діяльність. Правова визначеність висуває певні умови до реалізації владних повноважень, які $€$ незмінними незалежно від того, який статус має носій влади, що її здійснює.

Тривалий час проблемою здійснення державної влади було розмежування повноважень органів державної влади і місцевого самоврядування. Правова визначеність була порушена через дублювання функцій органів, спричинене невизначеністю у питаннях державного і місцевого значення, як наслідок, це викликало невиправдану затримку у наданні публічних послуг громадянам, протиставлення позицій державних і місцевих органів влади, щодо реалізації їхніх повноважень, які потрібно було вирішувати навіть через суд або шляхом прийняття окремого акта тлумачення, як це мало місце у Рішенні Конституційного Суду України від 13.10.2005 р. № 9-рп/2005 - справа про здійснення виконавчої влади і місцевого самоврядування в районах м. Києва.

Як зазначав 2011 р. В.П.Козуб, "чинна законодавча база обумовлює наявність широкої суміжної компетенції, яка перетинається (місцеві фінанси і бюджет; управління майном; питання забудови і благоустрою населених пунктів; питання землекористування й охорони навколишнього природного середовища; організація медичної допомоги населенню; керівництво установами охорони здоров'я, освіти, науки, культури, фізкультури і спорту). У результаті реалізація конституційного припису на розмежування компетенції органів місцевого самоврядування і місцевих державних адміністрацій набуває проблематичного характеру. Таке дублювання породжує необґрунтоване втручання одних органів у діяльність інших, що веде не до взаємодії, а до протистояння двох підсистем публічної влади на місцях і негативно відображається на ступені ефективності управління територіями" [2, с. 233].

Отже, проблема, що існувала на початку проведення реформи місцевого самоврядування характеризувалася невизначеністю повноважень різних органів влади, реформа частково подолала цю невизначеність, хоча відсутність чіткого адміністративно-територіального поділу громад ставить питання про повноваження 
органів на тій чи іншій території. Як зазначає О. В. Панухник, "дослідження існуючої ситуації у сфері адміністративно-територіального устрою України дозволило виявити низку проблем, серед яких відсутність у багатьох випадках визначених меж адміністративнотериторіальних одиниць або встановлення значної частини меж таких одиниць без урахування місцевих природних, історичних та інших факторів, перспектив розвитку регіонів і поселень. Це породжує постійні компетенційні суперечки між органами місцевого самоврядування й органами державної влади, зокрема щодо права власності на землю, місцевих податків тощо" [5, с. 78].

У реформі місцевого самоврядування, що переважно досліджується конституціоналістами і представниками адміністративного права, основна увага звертається на порядок організації представницьких органів, принципи діяльності місцевого самоврядування. Однак важливо відмітити, що децентралізація, яка і $€$ основною ідеєю реформи місцевого самоврядування, передбачає передачу повноважень від органів державної влади до органів місцевого самоврядування, тому важливо врахувати, що у ході реалізації таких повноважень одним із принципів, які мають застосовуватись, є принцип правової визначеності. Серед принципів організації місцевого самоврядування, цей принцип не значиться, радше через зосередженість переважно на спеціальних принципах організації органів місцевого самоврядування, аніж на загальних принципах права, які мають не менше значення для проведення децентралізації, аніж спеціальні. Як зазначає Х. В. Приходько, "у ході імплементації на національному рівні деякі базові поняття i принципи децентралізації публічної влади не знаходять уніфікованого сприйняття у подальшій реалізації в сучасній конституційно-проєктувальній діяльності" [8, с. 71]. Про важливість дотримання принципу верховенства права у процесі реформування місцевого самоврядування, складовою якого $є$ правова визначеність, зазначав В. Федоренко " іще одним вирішальним для місцевого самоврядування в Україні $\epsilon$ принцип верховенства права, який визначається ч. 1 ст. 8 Конституції України, як загальний для всіх правовідносин у сфері місцевого самоврядування... принцип верховенства права в місцевому самоврядуванні обґрунтовує повноту та невідчужуваність влади територіальної громади на місцевому рівні, ії̈ підпорядкованість виключно Конституції та законам України, а також колективним легітимним інтересам жителів конкретної територіальної громади" [11, с. 44]. На нашу думку, дія принципу верховенства права і правової визначеності щодо сфери місцевого самоврядування значно ширша.

Принцип правової визначеності як складова верховенства права часто називається принципом адміністративного права, хоча згідно з європейською правовою традицією цей принцип - невід'ємна складова верховенства права, обов'язковість застосування цього принципу виходить із конституційного положення про визнання і дію на території України принципу верховенства права. Правова визначеність передбачає чіткість і зрозумілість законодавчих положень, їхнє належне доведення до відома громадян, основною вимогою якого $\epsilon$ оприлюднення правових норм наперед і заборону зворотної дії правових норм; обов'язковість судових рішень та їхню неухильну виконуваність; повагу до легітимних очікувань громадян; обмеження дискреційних повноважень органів влади. Про необхідність дотримання принципу правової визначеності під час взаємодії місцевих органів державної влади і місцевого самоврядування в ході реалізації їхніх повноважень згадувалося, хоч і досить побіжно, ще до початку реформи місцевого самоврядування [12, с. 68]. Зверталась увага на дотримання вимог правової визначеності саме в ході реалізації повноважень цими органами.

Розглянемо окремі елементи правової визначеності щодо сфрери місцевого самоврядування.

Легітимні очікування. Однією з вимог правової визначеності $€$ повага до легітимних очікувань громадян, сформованих у ході неодноразового застосування органами влади положення законодавства, унаслідок чого у громадян формується очікування аналогічних дій у вирішенні схожих або подібних справ. Такі очікування заслуговують на увагу й органи влади повинні рахуватися з ними, якщо вони обґрунтовані, випливають із закону і не суперечать захисту законних прав інших осіб. На думку М. О. Петришиної, яка визнає застосування концепції легітимних очікувань до сфери місцевого самоврядування, легітимні очікування пов'язані 3 контролем із боку громадян за діями влади [6, с. 73$]$. Звертає на себе увагу той факт, що порівняно зі здійсненням влади органами держави, які вибудовано за принципом ієрархії і підпорядкування, відповідальність за порушення легітимних очікувань може наступати і через захист в адміністративному порядку - звернення до вищих органів, у той час, як у процесі здійснення цих самих повноважень органами місцевого самоврядування, залишається лише звернення до суду за захистом своїх легітимних очікувань. Численними $є$ справи, у яких громадяни звертаються до суду з позовами щодо неправомірних дії органів місцевого самоврядування, у яких суд доходить до висновку про порушення легітимних очікувань громадян їхніми діями. Зокрема, рішенням Черкаського окружного адміністративного суду від 29.03.2021 р. у справі № 580/577/21, суд задовольнив позов, визнавши протиправним відмову позивачу у видачі будівельного паспорта з посиланням на порушення легітимних очікувань позивача. Суд установив, що "характеристика очікувань як легітимних поєднує в собі: 1) їхню зацікавленість, яка зумовлена реалізацією особою належного їй суб'єктивного права; 2) їхню обґрунтованість, тобто зумовлену законом раціональність сподівань учасників суспільних відносин. У матеріально-правовому сенсі легітимні очікування мають захищатися від непередбачуваних змін законодавства, яким установлено відповідний режим (власності, інвестиційної діяльності тощо). У процедурному ж сенсі легітимні очікування стосуються однакової та послідовної правозастосовної практики. Суд переконаний, що у випадку відмови позивачу в забудові його земельної ділянки, відбувається порушення права на мирне володіння своїм майном, оскільки позивач позбавляється законних очікувань на забудову земельної ділянки, яка у встановленому законом порядку набута у власність. Позови до того ж самого органу, а саме департаменту архітектури, містобудування та інспектування Черкаської міської ради з вимогою визнати протиправними дії та зобов'язати видати будівельний паспорт були численними, принаймні у реєстрі судових рішень лише за період 2021 р. рішень тільки Черкаського окружного адміністративного суду налічується 6 і всі вони вказують на порушення органом місцевого самоврядування легітимних очікувань громадян. Це рішення у справі № 711/517/21 від 17.05.2021 р.; рішення у справі № 580/4223/20 від 11.02.2021 р.; рішення у справі № 580/3657/20 від 21.01.2021 р.; рішення у справі № 823/1392/18 від 18.05.2021 р.; справа № 580/5629/21 від 28.09.2021 р. Ця практика свідчить, що порушення легітимних очікувань пов'язується з визнанням протиправними дій органів місцевого самоврядування, а отже доводить, що дотримання принципу правової визначеності важливе саме в контексті здійснення повноважень органами місцевого самоврядування. 
Вимога визначеності і зрозумілості законодавства визнається актуальною М. А. Самбором у статті щодо реалізації права на свободу місцевих зібрань. Визнаючи практичне забезпечення цього права необхідною умовою демократичного суспільства, автор вказує на існування проблеми сповіщення органів місцевого самоврядування про намір провести таке зібрання. Невизначеність і незрозумілість цієї процедури визнаються порушенням правової визначеності. "Наявні законодавчі приписи про об'єкт сповіщення визначають об'єкт у загальному, застосовуючи альтернативний спосіб викладу норми, що не сприяє правовій визначеності та передбачуваності. Разом із тим такий стан справ із визначенням об'єкта сповіщення унеможливлює своєчасне та повне виконання обов'язку носієм права на свободу мирних зібрань, що може привести до необґрунтованого застосування заходів юридичної відповідальності" [10, с. 71].

Одним з елементів правової визначеності $є$ вимога обмеження дискреції, про яку згадують у контексті обмеження повноважень органів державної влади, однак питання $€$ не менш актуальним і стосовно місцевого самоврядування. Більше того, наявність права діяти у межах наданих повноважень у тих випадках, коли межі дискреції були порушені органами державної влади у процесі здійснення своїх повноважень, створюють потенційну ймовірність порушення і тоді, коли вони передані органам місцевого самоврядування. Незважаючи на зовсім інші принципи організації таких органів, дискреція при передачі повноважень, як правило зберігається, а тому ризик порушення ії̈ меж також має імовірність настання. Як зазначає В. О. Панкратова "досить часто при застосуванні принципу правової визначеності науковці наголошують, що він покликаний не допустити свавілля з боку органів державної влади чи органів місцевого самоврядування. Досягається такий ефект за допомогою чіткого встановлення меж дискреційних повноважень у нормативно-правових актах" [4, с. 406].

Одним із важливих елементів правової визначеності $\epsilon$ вимога оприлюднення нормативно-правових актів. Із розширенням повноважень органів місцевого самоврядування кількість і значення їхніх управлінських рішень значно зросли, вимога принципу правової визначеності щодо належного оприлюднення нормативних актів і доведення їх до громадян становить необхідну вимогу. Однак, якщо для оприлюднення актів органів державної влади застосовується спосіб опублікування поряд 3 оприлюдненням тексту в електронній формі, то оприлюднення нормативних актів органів місцевої влади переважно здійснюється на їхньому сайті. Досліджуючи це питання, Л. М. Андрусів зазначає, що "спостерігається тенденція оприлюднення нормативно-правових актів органами місцевого самоврядування на офріційних вебсайтах із використанням опублікування в окремих випадках. Однак ця тенденція має як позитивні, так і негативні якості. Серед позитивних характеристик електронного оприлюднення на офіційних вебсайтах можна вказати насамперед зручність у використанні та пошуку нормативно-правових актів органів місцевого самоврядування й економію матеріальних витрат. Однак електронне оприлюднення не гарантує вимоги загальнодоступності, оскільки не всі громадяни мають можливість доступу та необхідні навички в користуванні мережею інтернет" [1, с. 11]. Оскільки питання обрання форми оприлюднення нормативного акта належить до повноважень органу місцевого самоврядування, то слід здійснювати таке оприлюднення з урахуванням вимог правової визначеності. Оприлюднення $є$ етапом уведення в дію нормативного акта, а тому належне оприлюднення $€$ обов'язком самого органу і він несе відповідальність за доведення до громадян змісту його положень.

\section{ВИСНОВКИ}

У ході реформи місцевого самоврядування відбулася передача частини повноважень від органів державної влади до органів місцевого самоврядування. Принцип правової визначеності визнавався важливим у ході здійснення повноважень органами державної влади. 3 передачею цих повноважень органам місцевого самоврядування актуальність дотримання цього принципу залишається незмінною. Судова практика свідчить, що у діях органів місцевого самоврядування наявні непоодинокі випадки порушення легітимних очікувань, що є недопустимим і суперечить вимогам правової визначеності.

Дискусійним із позицій дотримання правової визначеності $€$ оприлюднення органами місцевого самоврядування своїх рішень, що здійснюється переважно через сайт. Таким чином, місцеве населення залишається не повною мірою охопленим такою інформацією, у цій частині з метою дотримання правової визначеності слід передбачити окрім електронного ще і доступний органам місцевого самоврядування альтернативний варіант оприлюднення рішень. Принцип правової визначеності вимагає дотримання чіткості законодавчих положень щодо адміністративно-територіального поділу, реалізації права на свободу місцевих зібрань, а також вимог обмеження дискреції.

У процесі реформування місцевого самоврядування та в ході реалізації повноважень органами місцевого самоврядування важливо дотримуватися загальних правових принципів, серед яких і принцип правової визначеності.

\section{Список використаних джерел:}

1. Андрусів Л.М. Особливість оприлюднення нормативно-правових актів органів місцевого самоврядування // Науково-інформаційний вісник Івано-Франківського університету права імені Короля Данила Галицького. Серія Право. 2019. № 8(20). С. 8-14.

2. Козуб В.П. Напрями підвищення результативності взаємодії органів державної влади і місцевого самоврядування в реалізації владних повноважены/ Актуальні проблеми державного управління. 2011. № 1(41). С. 231-240.

3. Коломоєць Т.О. "Антикорупційні" обмеження для осіб, уповноважених на виконання функцій держави або місцевого самоврядування: реалії використання "фільтру" правової визначеності в Україні// Актуальні проблеми вітчизняної юриспруденції. 2019. № 5. С. 84-89.

4. Панкратова В.О. Значення принципу правової визначеності при здійсненні публічної влади // Збірник тез IV Міжнародної науковопрактичної конференції, присвяченої світлій пам'яті доктора юридичних наук, професора, академіка-засновника НАПрНУ, першого голови Конституційного Суду України Леоніда Петровича Юзькова. 2-6 березня 2021 року. Хмельницький. 2021. 580 с. С. 405-407.

5. Панухник О.В. Адміністративно- територіальна реформа як чинник зміцнення місцевої економіки // Інноваційна економіка. 2014. № 3. C. $76-83$

6. Петришина М.О. Напрями удосконалення нормотворчості в органах місцевого самоврядування в Україні // Європейські перспективи, 2012. №2. ч. 2. С. 71-76.

7. Пилипів В.І. Право на службу в органах місцевого самоврядування: основи регламентації // Правові новели. 2021. Том 1. № 13. С. 74-80.

8. Приходько Х.В. Децентралізація публічної влади та місцеве самоврядування: концептуальні правові питання// Часопис Київського університету права. 2014. №4. С. 71-74.

9. Рішення Черкаського окружного адміністративного суду від у справі № 580/577/21. Режим доступу https://reyestr.court.gov.ua/Review/ 95898263

10. Самбор М.А. Органи місцевого самоврядування як об'єкти сповіщення про намір здійснення права на свободу мирних зібрань // Вісник ЛДУВС ім. Е.О.Дідоренка. 2019. Вип. 3 (87) С. 70-86.

11. Федоренко В. Принцип місцевого самоврядування в Україні: поняття, зміст і система // Історико-правовий часопис. 2017. № 2(10). С. 43-49.

12. Фуртатов В.С. Удосконалення механізму взаємодії органів виконавчої влади та місцевого самоврядування на сучасному етапі державотворення // Наукові праці, державне управління, політологія. Том 130. Випуск 117. С. 66-70.

13. Чернецька О.В. Представницькі органи місцевого самоврядування в системі публічної влади: конституційно-правова природа // Часопис Київського університету права. 2010. № 2. С. 119-123.

\section{References:}

1. Andrusiv L.M. Osoblivist opriludnennya normativno-pravovich aktiv organiv miszevogo samovryadyvannya /I Naukovo-informaziyniy visnik Ivano-Frankivskogo universitetu prava imeni Korolya Danila Galizkogo. Seria Pravo. 2019. № 8(20). P. 8-14. 
2. Kozub V.P. Napryami pidvichennya rezultativnosti vzaemodii organiv derzavnoi vladi I miscevogo samovryaduvannya $v$ realizacii vladnih povnovazen // Actualni problemi derzavnogo upravlinnya. 2011. № 1(41). povnovazen

3. Kolomoec T.O. Antikorupziyni obmegennya dlya osib, upovnovazenih na vikonannya funkciu derzavi abo miczevogo samovryaduvannya: realii vikoristannya filtru pravovoi viznacenosti v Ukraini $1 /$ Actualni problem vitchiznyanoi urisprudencii. 2019. № 5. P. 84-89.

4. Pankratova V.O. Znachennya principu pravovoi viznachenosti pri zdiysnenni publichnoi vladi// Zbirnik tez IV Miznarodnoi naukovo-praktichnoi conferencii, prisvyachenoi svitliy pamiati doctora yuridichnih nauk, profesora, akademika-pfsnovnika NAPRNU, pershogo golovi Constituziynogo Sudu Ukraini Leonida Petrovicha Yuzkova. 2-6 bereznya 2021 r. Khmelnizkiy. 580 p. pp.405-407.

5. Panushnik O.V. Administrativno-teritorialnareforma yak chinnik $z$ micnennya miscevoi economiki//Innovaciyna economica.2014. № 3. P. 76-83.

6. Petrishina M.O. Napryami udoskonalennya normotvorchosti v organah miscevogo samovryaduvannya v Ukraini // Evropeiski perspectivi. 2012. №2. p. 2. P. 71-76.

7. Pilipiv V.I. Pravo na sluzbu $v$ organah miczevogo samovryaduvannya: osnovi reglamentacii // Pravovi noveli. 2021. T.1. № 13. P.74-80.

H. Ostapenko, PhD (Law), Associate Prof.

Taras Shevchenko National University of Kyiv, Kyiv, Ukraine
8. Prichodko H.V. Decentralizacia publichnoi vladi ta misceve samovryaduvannya: conzeptualni pravovi pitannya // Chasopis Kuivskogo Universiyeyu prava. 2014 № 4. P. 71-74.

9. Rishennya Cherkaskogo okruzhnogo administrativnogo sudu № 580/577/21. Rezhim dostupu: https://reyestr.court.gov.ua/Review/95898263.

10. Sambor M.A. Organi miscevogo samovryaduvannya yak obyecti spovishcennya pro namir zdiysnennya prava na svobodu mirnich zibran // Visnyk LDUVS im. E.O. Didorenka. 2019. Vupusk. 3(87). P. 70-86.

11. Fedorenko V. Prinzip miscevogo samovryaduvannya $\vee$ Ukraini: ponyattya, zmist I systema// Istoriko-pravoviy chasopis. 2017. № 2(10). P. 43-49.

12. Furatov V.S. Udoskonalennya mechanizmu vzayemodii organiv vikonavchoi vladi I miscevogo samovryaduvannya na suchasnomy etapi derzhavotvorennya // Naukovi praci, derzavne upravlinnya, politologiya. Tom 130. Vipusk 117. P. 66-70.

13. Chernetska O.V. Predstavnizki organi miscevogo samovryaduvannya $\mathrm{v}$ sistemi publichnoi vladi: constituziyno-pravova priroda// Chasopis Kuivskogo Universiyeyu prava. 2010. № 2. P. 119-123.

Received: $29 / 09 / 2021$ Accepted: $15 / 10 / 2021$

\section{LEGAL CERTAINTY IN THE ASPECT OF LOCAL GOVERNMENT}

The article addresses the analyses of adherence to the legal certainty principle while the local government exercises its powers, which are enlarged during the reform of decentralization. It is stated that while the powers belonged to state government, the adherence of the legal certainty principle was found as very important to protect citizens from unpredictable and unequal treatment. So as soon as the powers were handed over to local government the protection of legal certainty principle still remains actual. Legal certainty requires clarity and legibility of legal provisions, limitation of discretive powers, promulgation and publication of legal acts in advance etc. These elements must be adhered realizing local powers.

One of the elements legal certainty requires is protection of the legitimate expectations of citizens. A number of court decisions which are analyzed in the article prove that breaking of legitimate expectations happens frequently. Emphasis is made on preventing such practices and on the need to respect legal certainty as a mandatory requirement of the rule of law.

The necessity of observance of the requirements of legal certainty at promulgation of acts by local self-government bodies and making the citizens know about them is determined.

Keywords: local self-government, legal certainty,certainty of law, rule of law, decenralization.

Bulletin of Taras Shevchenko National University of Kyiv.

Legal Studies, 2021; 4 (119): 63-69

удК 346.2; 347.1

DOI: https:doi.org/10.17721/1728-2195/2021/4.119-12
ISSN 1728-2195

(C) Taras Shevchenko National University of Kyiv, Publishing center "Kyiv University", 2021

П. О. Повар, канд. юрид. наук, доц. ORCID ID: 0000-0002-2057-5528

Київський національний університет імені Тараса Шевченка, Київ, Україна

\section{ПРАВОВЕ РЕГУЛЮВАННЯ ПРИПИНЕННЯ ФІЗИЧНОЇ ОСОБИ-ПІДПРИЄМЦЯ: ПОНЯТІЙНО-ТЕРМІНОЛОГІЧНІ ПРОБЛЕМИ}

Важливим елементом правового статусу фізичної особи-підприємця є умови позбавлення її статусу підприємця. Метою статті є визначення обсягу та змісту понятійно-термінологічного апарату правового регулювання припинення фізичної особи-підприємия, вироблення теоретичних положень і пропозицій щодо вдосконалення законодавств і практики правозастосування. Методологія дослідження ґрунтується на використанні історичного, системного, структурного методів, методів аналізу, синтезу й інших формально-логічних процедур.

У результаті дослідження історичного становлення законодавства України визначено та висвітлено логічний ряд розвитку понятійно-термінологічного апарату законодавчих актів. Обґрунтовано необхідність закріплення у кодифікованому акті у сфері підприємництва загальних положень щодо позбавлення статусу підприємця фізичною особою, зокрема і вживання відповідної термінології та понять. Сформульовано пропозиції щодо доповнення ГК України нормою щодо втрати фізичною особою статусу підприємця. Здійснено розмежування та встановлено співвідношення між поняттями "припинення підприємницької діяльності фізичною особою", "позбавлення статусу підприємця фізичною особою", "припинення фізичної особи-підприємия", "припинення суб'єкта господарювання". Досліджено та сформульовано положення щодо правової природи факту припинення підприємницької діяльності та факту позбавлення статусу підприємия фізичною особою. Визначено й обгрунтовано недоліки норм чинного законодавства, у яких не розмежовуються підстави припинення діяльності різної правової природи.

Запропоновано замінити термін "державна реєстрація припинення підприємницької діяльності фізичною особою" на термін "державна реєстрація позбавлення статусу підприємця фізичною особою" і внести відповідні зміни у законодавстві України. Обґрунтовано недоцільність вживання терміну "ліквідація" щодо фізичної особи-підприємия. Сформульовано визначення поняття "припинення фізичної особи-підприємця". Визначено можливість вживання поняття "позбавлення статусу підприємця фізичною особою" у вузькому та широкому значеннях.

Ключові слова: припинення підприємницької діяльності, фізична особа-підприємець, громадянин-підприємець, позбавлення статусу підприємия фізичною особою, припинення суб'єктів господарювання, державна реєстрація, ліквідація.

\section{ВСТУП}

Фізична особа-підприємець є однією з організаційноправових форм здійснення підприємницької діяльності, яка має широке застосування у практиці господарювання і займає вагоме місце у структурі товаровиробників національної економіки. Одним з елементів правового статусу фрізичної особи-підприємця є умови позбавлення такого статусу фізичною особою. На жаль, ні Господарський кодекс України [1] (далі - ГК України), ні Цивільний кодекс України [2] (далі - ЦК України) не регулю- 